\title{
Työtavasta ja filosofiasta professioksi
}

\author{
$+y$ \\ Ohjauksesta on haettu ratkaisua mitä moninaisimpiin ongelmiin. \\ Joskus on ollut tarpeen pohtia, mikä on ollut kysymys.
}

PROFESSORI SANNA VEHVILÄISEN tarkastelusSa ohjausta käsittelevien tekstien perusoletukset yhteiskunnasta asettuvat kolmijakoon: 1) yhteiskuntaaffirmatiiviset, 2) kriittiset sekä 3) yhdistelevät ja välittävät. Sosiologisesti ja biopoliittisesti orientoituneet tutkimukset ja useat toimintakäytäntöjen kuvaukset ovatkin asettuneet usein toisiaan vastaan: tiedeartikkeleiden kriittinen ote yhtäällä ja ohjauksen konsulttikäytännöt toisaalla kuvaavat hyvin kahta eri todellisuutta.

Yhdistelevät ja välittävät näkökulmat paikannamme ohjauksen ammattiorientoituneisiin toimijoihin, joiden intentiot löytyvät ensisijaisesti ohjaustyön kehittämisestä. Käytännön kehittämiselle vastakkainen näkökulma oikeuttaa ohjauksen taloudellisella hyödyllä. Vastakkainen kehittämisintentiolle on myös ohjauksen palauttaminen joko psykologissosiaalisiin tai biopoliittisiin alistamiskäytäntöihin. Biopoliittisissa näkemyksissä kritisoidaan sitä, kuinka ihmiskehon ja -mielen, ruumiin ja psyyken hallinta kulkeutuu yksilöihin kohdistuvassa auttamistyössä menetelmiensä kautta koko ihmisen elämään; ne kääntävät auttamisen hallinnaksi ja yhteiskunnalliset epäkohdat yksilöllisiksi (Brunila ym. 2015).

Vehviläisen mukaan ohjauksen tutkimuksen metodologisessa muutoksessa yhteiskuntakriittinen näkökulma "[h]älveni urateoriasta taka-alalle yksi- löiden 'tarinoituessa”. Yksilöt ja todellisuus ikään kuin häipyivät reaalisista konteksteistaan teksteiksi tarinoihin. Sama tapahtui köyhyystutkimuksessa, jossa nälästä tuli eräs laadullinen narratiivi, kunnes kvantitatiivinen tutkimus palautti tietoomme todella nälkäisten määrän Suomessa. Kertomuksellisuuden haitoista ja ylilyönneistä on viime vuosina keskusteltu aiempaa enemmän (Mäkelä ym. 2020), mutta tämä ei vielä ole kovinkaan hyvin näkynyt Aikuiskasvatuksessa.

\section{AIKUISKASVATUSTIETEEN ITSEYMMÄRRYSTÄ ON HAETTU MONISTA LÄHTEISTÄ}

Työtapana ja filosofiana ohjauksen synty 1900-luvun alussa ja muutokset sen jälkeen ovat paikannettavissa aina jonkin ongelman ratkaisuun jossakin, esimerkiksi uran, opintojen, työn, perheen tai johtamisen, kontekstissa. Jos ohjaus on ollut vastaus moninaisiin ongelmiin, jälkikäteen on pitänyt pohtia myös, mikä on kulloinkin ollut kysymys. Praktista vaihetta ovat aina seuranneet teoretisointi ja filosofinen pohdinta. Rogerslainen "suuri keksintö" 1950-luvulla johti asiakkaan (client) asettamiseen toiminnan keskiöön ja subjektiksi: asiakkaan omat pyrkimykset ovat auttamisen lähtökohtina ja tavoitteina, ja ammattilainen asettuu hänen "asianajajakseen". 
Ohjaus on myös joutunut puolustamaan eettisiä lähtökohtiaan ja olemustaan soveltamiskontekstiensa muutoksissa, joissa yleensä muut kuin ensisijaiset asiakkaat ovat ottaneet ohjauksen menetelmiä omia tarkoitusperiään hyödyntävään käyttöön (Pasanen \& Vanhalakka-Ruoho 2012). Tuorein ohjauksen hyötykäyttäjä on uusliberalistinen talous- ja koulutuspolitiikka, joka muutti jo 1990-luvun alussa esimerkiksi ammatillisen aikuiskoulutuksen kauppatavaraksi (Onnismaa \& Pasanen 2015). Samoihin aikoihin useita ohjausammatteja alettiin muotoilla konsulttitoiminnaksi niiden alkuperäisen eettisen intention kustannuksella.

Aikuiskasvatustieteen suuria kertomuksia ovat olleet muun muassa tasa-arvo, itseohjautuvuus ja aikuinen oppija, andragogia, vapaa sivistystyö, työelämän aikuiskoulutus, jatkuva kasvatus ja elinikäinen oppiminen. Tasa-arvon idea on vanhin ja säilynyt edelleen feminismin kantamana ja uusliberalismin negatiivisten seurausten tuella potentiaalisesti elinvoimaisena. Itseohjautuvuuden aikakausi alkoi 1980-luvun puolivälissä ja teoreettisesti aikuiskasvatuksessa kiinnostavana loppui 2000-luvun alussa. Konstruktivismin vaikutus on kulkenut 1990-luvun lopulta toimijuuden ja tutkivan oppimisen tutkimuksessa. Tutkimuksen käytäntökonteksteina vapaa sivistystyö ja työelämän aikuiskoulutus ovat säilyneet vahvoina kuten myös sosiologinen tutkimusorientaatio. Missään aikuiskasvatustieteen akateemisessa yksikössä ei kuitenkaan ole varsinaista aikuisten ohjaukselle orientoitunutta perustutkimusta tai opintojen osiota.

Aikuiskasvatustieteen itseymmärrys on vuosikymmenten kuluessa haettu monista lähteistä (ks. Filander ym. 2010; Salo 2006). Kuten kasvatustieteet yleisesti, aikuiskasvatuskaan ei ole muodostanut pysyvää tai yhtenäistä tieteenalaa tai kypsää tutkimusparadigmaa (Rinne ym. 2015). Vaikka moni- ja poikkitieteisyys rikastuttavat teoretisointia, on ongelmallista, jos näkökulmat eivät edes pyri keskustelemaan toistensa kanssa tai muodostavat suljettuja piirejä ja hyljeksivät toisiaan. Pienten yksiköiden yhteistyötä ei käytetä myönteisesti lisäarvoa tuottavalla tavalla. Voisiko aikuisohjauksesta muodostua yhdistävä tekijä tai olennainen kehittämiskohde aikuiskasvatustieteessä?

\section{AIKUISKASVATUS JA -OHJAUS OVAT TOISIINSA SIDOKSISSA}

Aikuiskasvatus ja ohjaus kytkeytyvät periaatteessa toisiinsa toimintojensa käytännöissä ja konteksteissa. Filosofisesti ja eettisesti ne ovat toisiinsa sidoksissa, koska molemmissa ihminen ja asiakas käsitetään täysi-ikäiseksi ja suvereeniksi toimijaksi, niiden julkiintentio on kehitysoptimistinen ja ne hakevat teoriaansa ja metodologiaansa samoista perustieteistä (ks. mt.; Spangar ym. 2000).

Teoreettisesti aikuiskasvatuksen ja ohjauksen kytkentä ei ole kuitenkaan onnistunut, ja kumpikin on jäänyt toimintakontekstiensa yhteisen tutkimuksen suhteen torsoksi. Suomalaisessa aikuiskasvatustieteessä on hyljeksitty pedagogista tai andragogista toiminnan tasoa. Ohjauksessa taas on korostunut pulmatilanteissa olevien ihmisten auttamisen yksilönäkökulma ja psykologispainotteinen teoretisointi. Aikuiskasvatustieteen itseymmärrykselle olisikin kiintoisaa tutkia, millaista andragogiikkaa akateemisen aikuiskasvatuksen opinnoissa toteutetaan (vrt. Heikkinen \& Kallio 2014).

Aikuiskasvatuksen ja ohjauksen kehittämisen yhteistä projektia ja tulevaisuutta voitaisiin hakea juuri andragogisen toiminnan tasolta, sieltä missä opetus, kasvatus ja ohjaus tapahtuvat pedagogisissa suhteissa. On mielenkiintoista, että biopoliittisen vallankäytön tutkija ja kriitikko Maurizio Lazzarato (2006) näkee pedagogisen - ja oletettavasti andragogisen - suhteen strategisena ihmisten välisenä suhteena, jota ei märritä ennalta institutionaalinen hallintavalta. Pedagoginen suhde ei ole periaatteellinen alistussuhde, vaan se toteutuu ja on analysoitava suhteen toimintojen perusteella. Tällä tavoin voidaan odottaa - Vehviläisen lailla - tästä näkökulmasta avautuvaa aikuiskasvatustiedettä ja ohjaustutkimusta toisiinsa sitovaa kriittistä ja käytännöllistä tutkimusta niin, että ne yhdistyvät myös muussa todellisuudessa kuin Aikuiskasvatuksessa.

\section{OHJAUSPOLITIIKKA JA OHJAUKSEN ARVIOINTI}

2020-luvulla vähälle huomiolle jääneet, toisiinsa liittyvät näkökulmat ohjauspolitiikka ja ohjauksen 
arviointi poikivat joitain puheenvuoroja 2000-luvun alun Aikuiskasvatuksessa. Eri maissa on painotettu elinikäistä ohjausta (life long guidance). Talousjärjestö OECD ja Euroopan komissio ovat ajoittain tuoneet esiin, että riittävä neuvonta ja ohjaus ovat välttämättömiä elinikäiselle oppimiselle ja elämän siirtymävaiheiden läpikäymiselle (OECD 2020; OECD 2003; EU 2004). Sanna Marinin (sd) hallitusohjelmassa painotetaan elinikäistä ohjausta, jotta voidaan tukea osaamista ja aliedustettujen ryhmien osallistumista jatkuvaan oppimiseen.

Ohjaus on myös poliittinen prosessi, jonka ulottuvuuksia ja jännitteitä ovat yksilölliset ja yhteiskunnalliset tarpeet sekä yksityiset ja julkiset identiteetit. Jos OECD ja sen myötä kansalliset politiikat ovat pitkään pitäneet koulutusta talouskasvun moottorina, ohjausta on alettu pitää moottorin voitelijana. Yksilön työja elämänuraa voi tarkastella yksilöllisen toiminnan, talouden ja sosiaalisten rakenteiden leikkauskohtana (Young \& Collin 2001; Plant 1995). Ohjausalan yhteistyön käännekohtana voidaan pitää Career development and public policy -prosessia, johon mukaan tulivat OECD, Europan komissio, kansainvälinen työjärjestö ILO ja Maailmanpankki sekä ohjausammattilaisia ja -tutkijoita ja päättäjiä 20 maasta.

Ohjaus voi olla poliittista, mutta päätöksenteko ei ole loogista, lineaarista tai rationaalista. Koulutuspolitiikan tutkija Steven Ballin mukaan (2001) kansallinen politiikanteko on eräänlaista nikkarointia ja yhteen liimailua. Irrotetaan käyttökelpoisilta näyttäviä osia teorioista ja muoti-ilmiöistä. Noudatetaan apostoli Paavalin ohjetta "Koetelkaa kaikkea ja pitäkää se, mikä on hyvää". Voi käydä niinkin, että hallinnossa askarrellut käsitteet otetaan sellaisinaan koulutus- ja ohjaustutkimukseen.

1900-luvun lopun vähittäinen siirtymä hyvinvointivaltiosta kilpailukykyvaltioon merkitsi myös siirtymää kansalaisuutta ja demokratiaa korostavasta hallinnosta (government) kohti verkostoja, vertaisarviointia ja sopimuksia painottavaa hallintaa ( $g o-$ vernance). Puheavaruudessa on 1990-luvun alusta sinkoillut muutosta, joustavuutta, kannustavuutta, kilpailukykyä, huippuosaamista, osaamisvajetta ja innovointia. Näennäisestä epänormatiivisuudestaan huolimatta hallinnan normatiivisuus on vahvaa.
Hallinnosta hallintaan siirtyminen toi muassaan arviointikulttuurin. OECD on todennut (2003), että ohjaus voi vaikuttaa välittömästi hakeuduttaessa koulutukseen, työhön tai kuntoutukseen. Pitkän aikavälin tulokset koskevat valitulla ammattialalla viihtymistä tai oman osaamisen kehittämistä. Oppilaitostasolla ohjaus on laaja-alainen toimintajärjestelmä ja organisaation strategiatason arvovalinta, jonka toteutuksessa on monia osallisia ja vastuullisia.

Aikuiskasvatuksessa tuotiin esiin, että ohjausammattilaisten tulisi asiantuntijoina osallistua ohjauksen toivottavien tulosten ja arviointikriteerien määrittelyyn sen sijaan, että he odottelisivat muiden tahojen määrittelyjä. Kehittymättömät arvioinnin mittarit herättävät huolta, mutta ohjauksen arviointihankkeet voivat parantaa eri ohjaustahojen yhteistyötä ja auttaa tuomaan ura- ja elämänsuunnittelun kysymyksiä päättäjien asialistalle (Onnismaa 2003; 2005).

Sanna Vehviläinen toteaa, että nykyään alkaa jo olla tarjolla myös tapoja mitata muutosta, kuten uramuuntuvuutta, työhyvinvointia, työ- ja opiskelukykyä sekä ammatillista toimijuutta. Tästä houkuttaisi lukea lisää Aikuiskasvatuksessa.

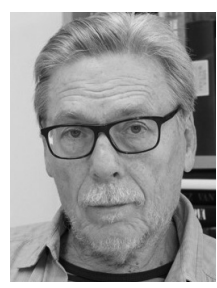

JUSSI ONNISMAA

FT, dosentti, työnohjaaja

(D) https://orcid.org/0000-00018822-5746

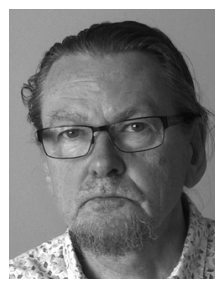

HEIKKI PASANEN

FT, yliopettaja emeritus 


\section{LÄHTEET}

Ball, S. (2001). Performativities and fabrication in the education economy: Towards the performative society. Teoksessa D. Gleeson \& C. Husbands (toim.) The Performing school: Managing, teaching, and learning in a performance culture. London: Routledge.

EU (2004). Euroopan unionin neuvosto. Ehdotus: Neuvoston ja neuvostossa kokoontuvien jäsenvaltioiden hallitusten edustajien päätöslauselma politiikkojen, järjestelmien ja käytäntöjen tehostamisesta elinaikaisen ohjauksen alalla Euroopassa. 9286/04. EDUC.

Brunila, K., Onnismaa, J. \& Pasanen H. (2015). Johdanto. Teoksessa K. Brunila, J. Onnismaa, \& H. Pasanen (toim.) Koko elämä töihin: Koulutus tietokykykapitalismissa. Aikuiskasvatuksen 52. vuosikirja. Tampere: Vastapaino, 9-24.

Filander, K., Jauhiainen, A., Onnismaa, J., Saloheimo, L., Silvennoinen, H. \& Valkama, H. (2010).

Aikuiskasvatustieteen tila ja tulevaisuus. Aikuiskasvatus, 30(3), 213-223. https://doi. org/10.33336/aik.93884

Heikkinen, A. \& Kallio, E. (toim.) (2014). Aikuisten kasvu ja aktivointi. Tampere: Tampere University Press.

Lazzarato M. (2006). Kapitalismin vallankumoukset. Helsinki: Tutkijaliitto.

Mäkelä, M., Björninen, S, Hämäläinen, V. Karttunen, L., Nurminen, M., Raipola, J. \& Rantanen, T. (2020). Kertomuksen vaarat. Kriittisiä ääniä tarinataloudessa. Tampere: Vastapaino

OECD (2003). Career Guidance and Public Policy: Bridging the gap. Guidance policies in the knowledge society trends, challenges, and responses across Europe. https://www.oecd.org/education/innovationeducation/34050171.pdf

OECD (2020). Continuous Learning in Working Life in Finland: Getting skills right. Paris: OECD Publishing.

Onnismaa, J. (2003). Ohjauksen arviointi tuo päättäjät ja ohjauksen ammattilaiset samaan keskusteluun. Aikuiskasvatus, 23(3), 248-253. https://doi. org/10.33336/aik.93506
Onnismaa, J (2005). Ohjaus aikuisoppilaitoksissa arvioitu. Aikuiskasvatus, 25(2), 147-149. https://doi. org/10.33336/aik.93621

Onnismaa, J. \& Pasanen, H. (2015). Identiteetit markkinoilla. Teoksessa K. Brunila, J. Onnismaa, \& H. Pasanen (toim.) Koko elämä töihin: Koulutus tietokykykapitalismissa. Aikuiskasvatuksen 52. vuosikirja. Tampere: Vastapaino, 245-281

Pasanen, H. \& Vanhalakka-Ruoho, M. (2009). Ohjaustyö ja osallisuus: Sisäistettyjä siteitä vai kasvavaa kontrollia. Teoksessa K. Filander \& M. Vanhalakka-Ruoho, (toim.) Yhteisöllisyys liikkeessä. Aikuiskasvatuksen 48. vuosikirja. Helsinki: Kansanvalistusseura ja Aikuiskasvatuksen tutkimusseura, 299-324.

Plant, P. (1995). Economy and ecology. Teoksessa Y. Bartholomeus, E. Brongers \& S. Kristensen (toim.) The Quest for Quality: Towards joint European quality norms. The Netherlands: National Careers Guidance Information Centre, 39-42.

Rinne, R., Kivirauma, J. \& Lehtinen, E. (2015). Johdatus kasvatustieteisiin. 8. painos. Jyväskylä: PS-kustannus.

Salo, P. (2006). Mitä on suomalainen aikuiskasvatustutkimus? Aikuiskasvatus, 26(4), 289295. https://doi.org/10.33336/aik.93719

Spangar, T., Pasanen H. \& Onnismaa J. (2000). Alkusanat. Teoksessa J. Onnismaa, H. Pasanen \& T. Spangar (toim.) Ohjaus ammattina ja tieteenalana I. Jyväskylä: PS-kustannus, 5-21.

Vehviläinen, S. (2021). Itseohjautuvuudesta osallisuuteen. Ohjaus Aikuiskasvatuksessa vuosina 1996-2021 Aikuiskasvatus, 41(4), XXX-XXX.

Young, R. \& Collin, A. (2000). Introduction: Framing the future of career. Teoksessa A. Collin \& R. Young (toim.) The Future of Career. Cambridge: Cambridge University Press, 1-17. 